\title{
EFFICIENT FLOOR SHAPE OF THE HIGH RISE STRUCTURE WITH RESPECT TO THE SEISMIC LOADING: A COMPARATIVE STUDY
}

\author{
Md. Mahbub-ul-Alam ${ }^{1}$, Farjana Akter ${ }^{2}$ \\ ${ }^{1}$ Assistant Professor, Department of Civil Engineering, Stamford University Bangladesh, Dhaka, Bangladesh \\ ${ }^{2}$ Lecturer, Department of Civil Engineering, Stamford University Bangladesh, Dhaka, Bangladesh
}

\begin{abstract}
One of the most important design criteria for high rise structures is its shape because it provides the outer size, outlook as well as orientation of the building. As the height of the structure increases, the impacts of lateral loading become higher. To resist the lateral loads, we need to bring out alternative procedure which may help us to reduce this effects so that we can build safe and sound tall buildings. The shape of the structure usually comes from its floor orientation and size. Based on this consideration, this study focuses on the responses by analyzing the effects of the lateral loads specially earthquake on two 20 storied high rise structures, one with square floor shape and another with circular floor, having similar floor areas with edge supported floor systems. The study reveals that circular shape is the preferable floor area as it can resist more storey shears and overturning moments compared to square shape though circular shape structure is found less stiff than square shape structure.
\end{abstract}

Keywords: Building Shape, Circular Floor System, Earthquake Loading, Square Shape Floor, Tall Buildings

\section{INTRODUCTION}

One of the most important design criteria for high rise structures is its shape because it provides the outer size, outlook as well as orientation of the building. As the height of the structure increases, the impacts of lateral loading become higher. To resist the lateral loads, we need to bring out alternative procedure which may help us to reduce this effects so that we can build safe and sound tall buildings. The shape of the structure usually comes from its floor orientation and size. The shape of a structure is defined as its height, width and depth [5].

\section{BACKGROUND OF STUDY}

In the recent years, Bangladesh has growing trends towards the construction of multi-storied buildings. Almost of these skyscrapers are being constructed in Dhaka city. For this reason, these types of skyscrapers are being affected by lateral loading. The structural frames of tall buildings must carry vertical gravity loads, but lateral loads are also a major consideration [1], [3]. Lateral loads are always applied horizontally. Wind loads and earthquakes are mainly considered as lateral loads. Earthquake loads are particularly important in the design of large structures, such as tall buildings, that have large open interiors and walls in which large openings may occur. Variation of seismic effects with height must be considered in the design of tall structures [2]. If the EQ effects are not properly considered in the design, then the structure will produce lateral deflection, i.e. sway and the resident of the structure will feel dizziness, headache and other uncomfortable feelings.

\section{OBJECTIVES OF THE STUDY}

- To observe the effects of earthquake load on different structural outer shape of high rise building especially circular \& square floor system in terms of maximum story displacement, maximum story drift, story shear, overturning moment, story stiffness etc. of different building elements.

- To find out the best structural shape with respect to earthquake loading.

\section{METHODOLOGY OF THE STUDY}

Two 20 storied frame structures having same plinth areas with edge supported floor system had been selected. The both structures have residential floors.

Type-I building- Circular Shape Structure as shown in Fig. 1.

Type-II building-Square Shape Structure as shown in Fig.2.

\section{Square Shape Structure-}

Length of building, B

Width of building, $\mathrm{L}$

$=90 \mathrm{ft}$

Height of building, $\mathrm{H}$

$=90 \mathrm{ft}$

$=200 \mathrm{ft}$

\section{Circular Shape Structure-}

Diameter or least horizontal dimension of building, $\mathrm{D}=51 \mathrm{ft}$ Height of building, $\mathrm{H}$

$=200 \mathrm{ft}$

Seismic factor-

Seismic zone Coefficient, Z

$=0.150$

Special moment resisting frame, $R$

$=12$

Importance Coefficient for residential building, $I \quad=1.0$

Soil profile, $\mathrm{S}$

$=1.5$

Vibration time period, $T(\mathrm{sec})$ 


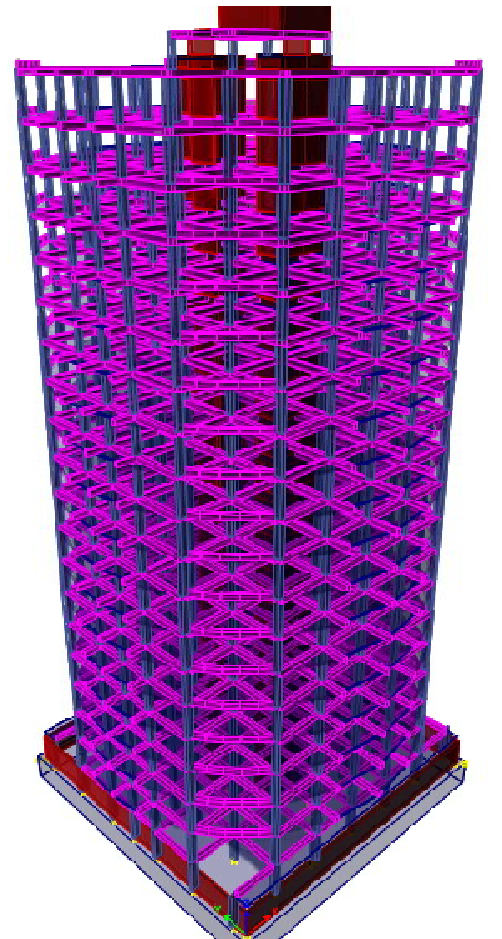

Fig-1: 3-D side view of the Type-I structure (circular shape)

\subsection{Design data and Specifications Considered in the Study}

According to the main objective of this study, the whole comparative study is divided into several sub topics so that a clear picture can be obtained and complete discussions are possible.

The whole study was carried out based on few considerations and specifications which are summarized in Table-1.

Table-1: Summary of the design considerations and specification of the study

\begin{tabular}{|c|c|}
\hline Items & Description \\
\hline Design code & $\begin{array}{l}\text { American Concrete Institute }(A C I) \\
\text { Building design code, } 2011 \text { [6]. } \\
\text { BNBC Code [5] } \\
\text { Uniform Building Code (UBC), } 1994 .\end{array}$ \\
\hline Loadings & $\begin{array}{l}\text { Floor plus ceiling finish }=30 \mathrm{psf} \\
\text { Live load }=40 \mathrm{ps} f \\
\text { Partition wall=70 psf } \\
\text { Earthquake loads as per UBC } 1994 .\end{array}$ \\
\hline $\begin{array}{l}\text { Building } \\
\text { components }\end{array}$ & $\begin{array}{l}\text { Column type }=\text { Tied } \\
\text { Footing type }=\text { Mat foundation. } \\
\text { Thickness of all walls }=5 \text { inch. }\end{array}$ \\
\hline $\begin{array}{l}\text { Material } \\
\text { properties }[1] \text {, } \\
{[4]}\end{array}$ & $\begin{array}{l}\text { Yield strength of reinforcing bars, } \\
f_{y}=60,000 \mathrm{psi} . \\
\text { Concrete comp. strength, } \\
f_{c=4,000}^{\prime} \text { psi. } \\
\text { Normal density concrete, unit wt. } \\
w_{c}=150 \mathrm{pcf} . \\
\text { Unit weight of brick, } \\
w_{b}=120 \text { pcf. }\end{array}$ \\
\hline
\end{tabular}

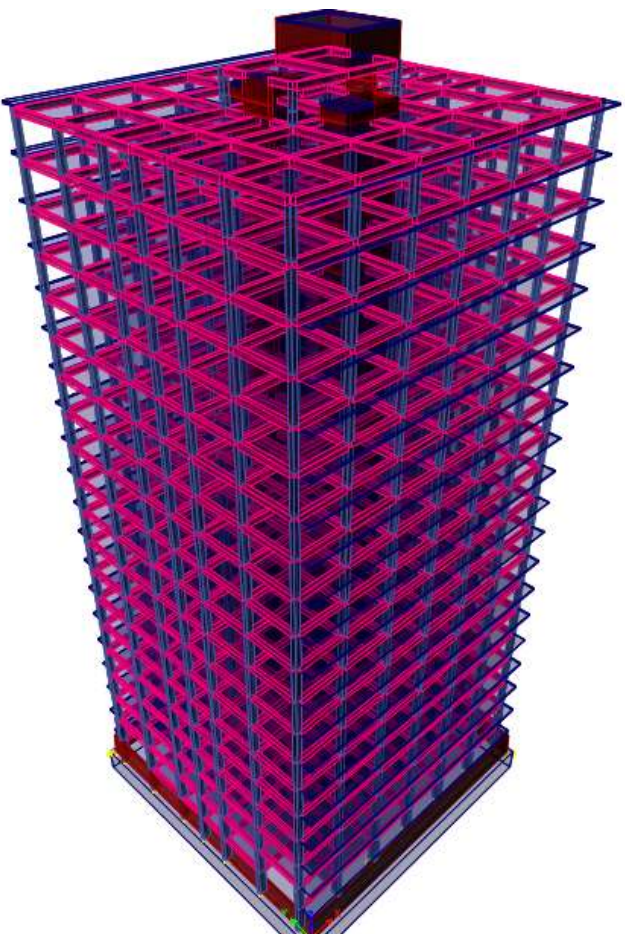

Fig-2: 3-D side view of the Type-II structure (square shape)

\section{RESULTS \& DISCUSSIONS}

This section will present the differences among the responses of Circular and Square Structures towards EQ loading in terms of the following factors:

- $\quad$ Lateral Loads to Stories

- Auto Lateral Loads to Stories

- Maximum Story Displacement

- $\quad$ Maximum Story Drifts

- Story Shears

- $\quad$ Story Overturning Moments

Comparative analysis was done by ETABS 2013. The global $\mathrm{X}$-axis of the model is parallel to the long direction and global $\mathrm{Y}$-axis is parallel to the short direction of the building. The global $\mathrm{X}$-axis and $\mathrm{Y}$-axis of the two models are shown in Fig-3 and Fig.-4 respectively. 


\section{ETABS 2013 - Circular}

File Edit View Define Draw Select Assign Analyze Display Design Detailing Options Help

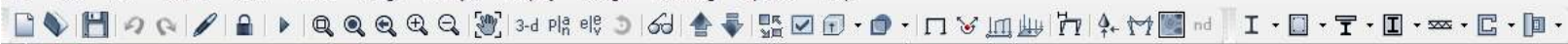

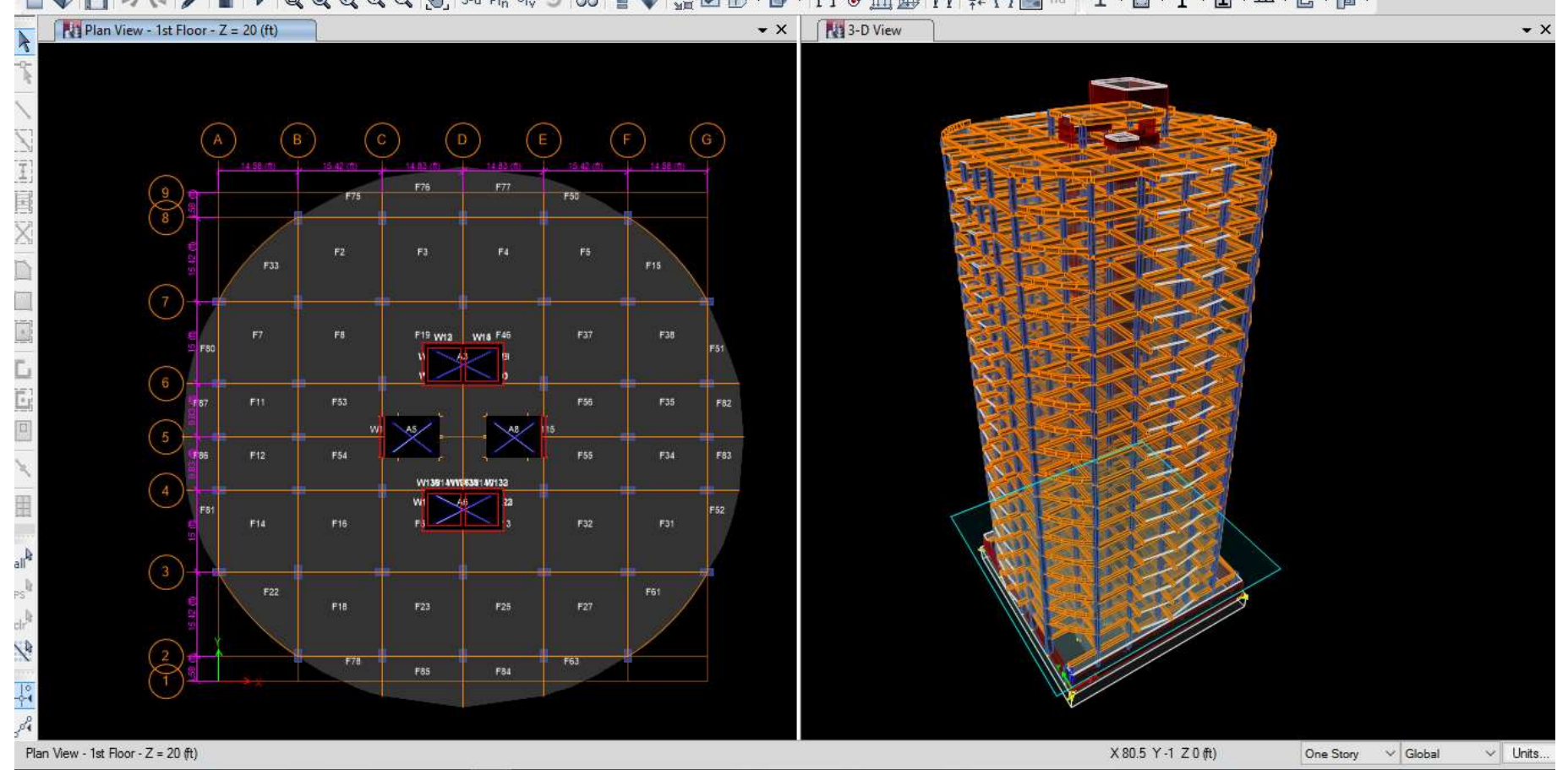

Fig-3: Global X \& Y Direction of ETABS Model (Circular)

W11 ETABS 2013 - Square 2

File Edit View Define Draw Select Assign Analyze Display Design Detailing Options Help

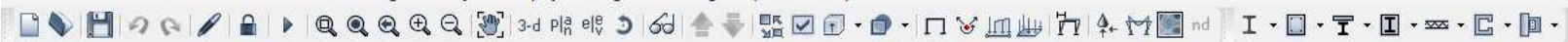

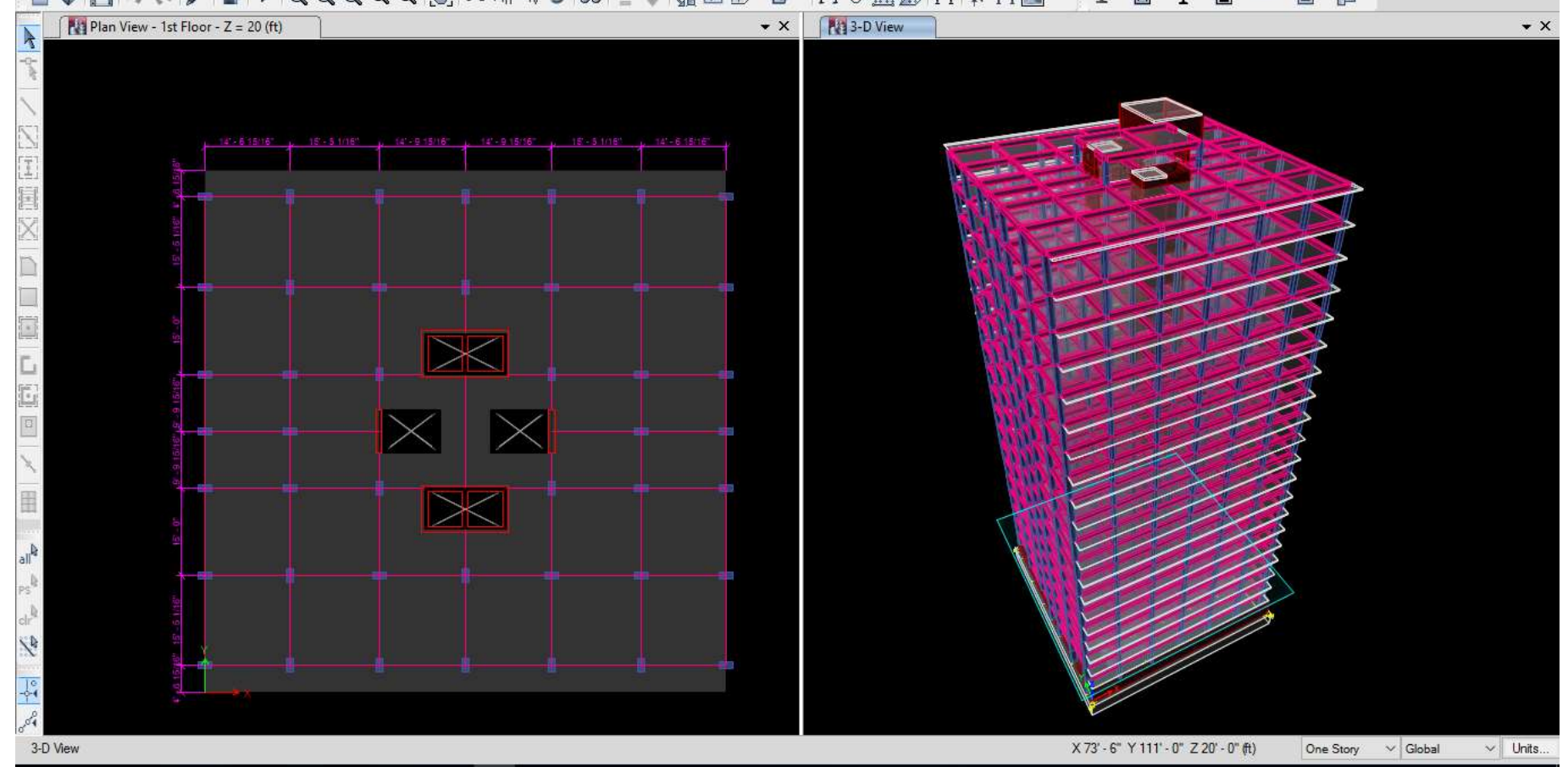

Fig-4: Global X \& Y Direction of ETABS Model (Square)

5.1 Maximum Story Displacement Resisted at each

\section{Storey}

Fig.5(a b) provide information about the response for maximum story displacement. Here the horizontal axis represents displacement in inch and the vertical axis represents the stories of the building. Blue curves state the response due to lateral loads implying in $\mathrm{X}$ direction of the model and red curves in $\mathrm{Y}$ direction. From figures, it is clearly seen that maximum displacement at roof top is 4.04 and 4.43 inch for square shape and circular shape structure in $\mathrm{X}$-direction respectively. Similarly, respective displacements are 4.48 and 5.02 inch in $\mathrm{Y}$-direction. 


\subsection{Maximum Story Drifts}

Fig $6(a \sim b)$ give story drifts. Here the horizontal axis represents drifts and the vertical axis represents the number of the stories of the building. Blue curves state the response due to lateral loads implying in $\mathrm{X}$ direction of the model and red curves in $\mathrm{Y}$ direction. From figure it is clearly seen that, the storey drift form a parabolic shape with zero drift at bottom, increases toward mid and finally decreases again at top. From figures, it is clearly seen that maximum drift at $10^{\text {th }}$ floor level is 0.002057 and 0.002257 for square shape and circular shape structure in X-direction respectively. Similarly, respective drifts are 0.002433 and 0.002725 at $8^{\text {th }}$ floor level in Y-direction.

\subsection{Story Shears}

Fig 7(a b) provide information about the response for story shears. Here the horizontal axis represents story shear in kips and the vertical axis represents the stories of the building. Blue curves state the response due to lateral loads implying in $\mathrm{X}$ direction of the model and red curves in $\mathrm{Y}$ direction. From figures, it is clearly seen that maximum shear at ground floor level is 849.58 kip and 919.41 kip for square shape and circular shape structure in both directions respectively.

\subsection{Resisting Story Overturning Moments [MR]}

Fig $8(\mathrm{a} \sim \mathrm{b})$ show the response for story overturning moments. Here the horizontal axis represents overturning moments in kip-inch and the vertical axis represents the stories of the building. Blue curves state the response due to lateral loads implying in $\mathrm{X}$ direction of the model and red curves in $\mathrm{Y}$ direction. From figures, it is clearly seen that, curve starts from base with its peak value and sharply goes down to $18^{\text {th }}$ story in both WX and WY. It is noted here that due to lateral loads in $\mathrm{X}$-direction, the whole structure will resist its overturn with respect to $\mathrm{Y}$-axis and creates a resisting overturning moment with respect to Y-axis. Similar case can be explained for loads in Y-direction. However, it is shown that circular shape structure can withstand greater storey overturning moment (127593\& $124573.8 \mathrm{k}-\mathrm{ft}$ ) compared to square shape structure (118255 \&115574.21 k-ft) in X and Y directions respectively.

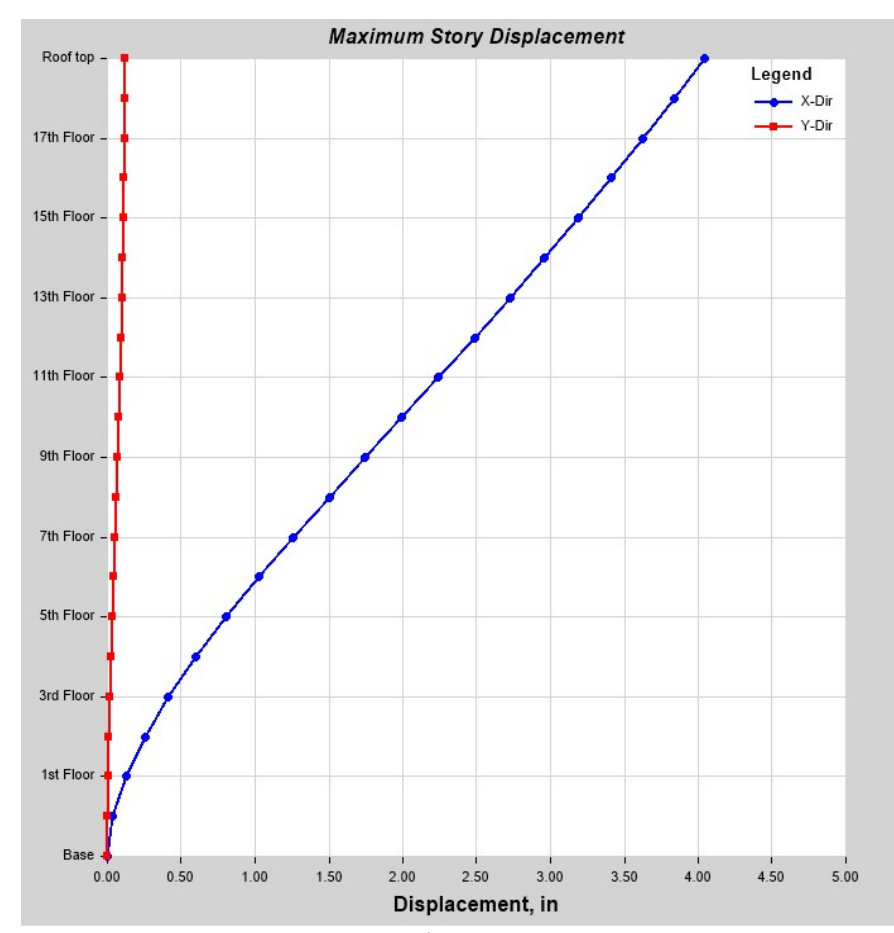

Square Shape Structure

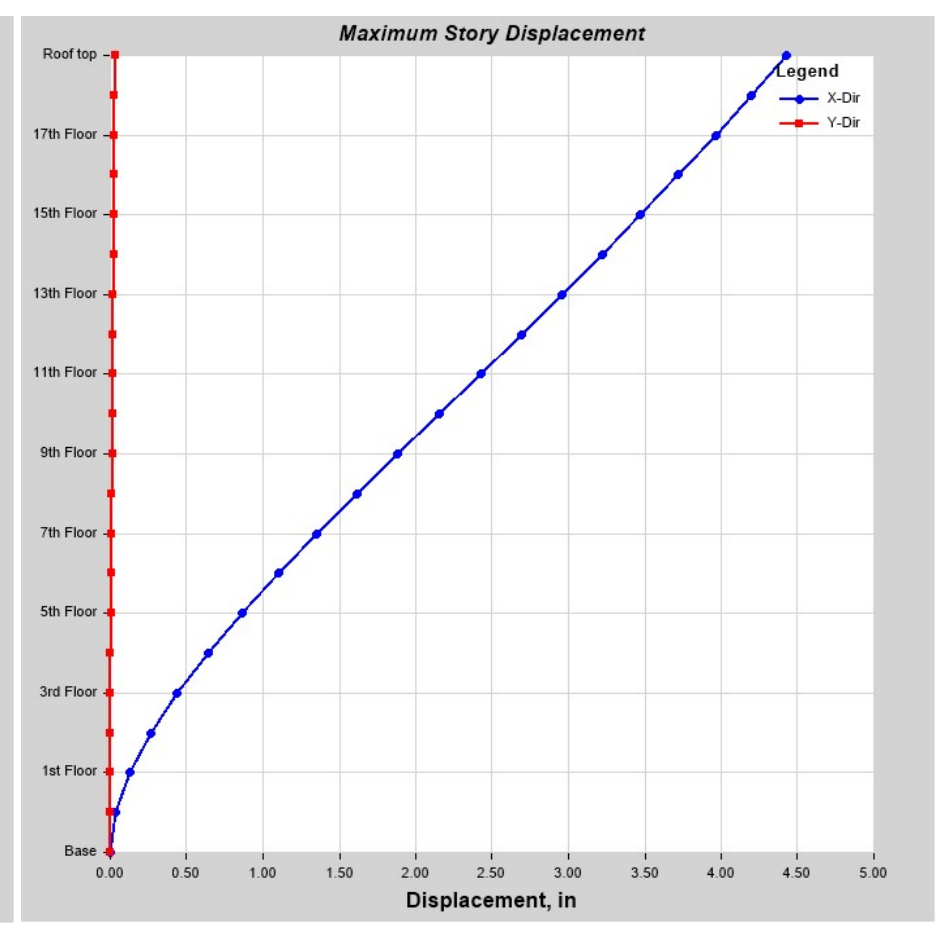

Circular Shape Structure

Fig-5a: Maximum Story Displacement in global X direction 


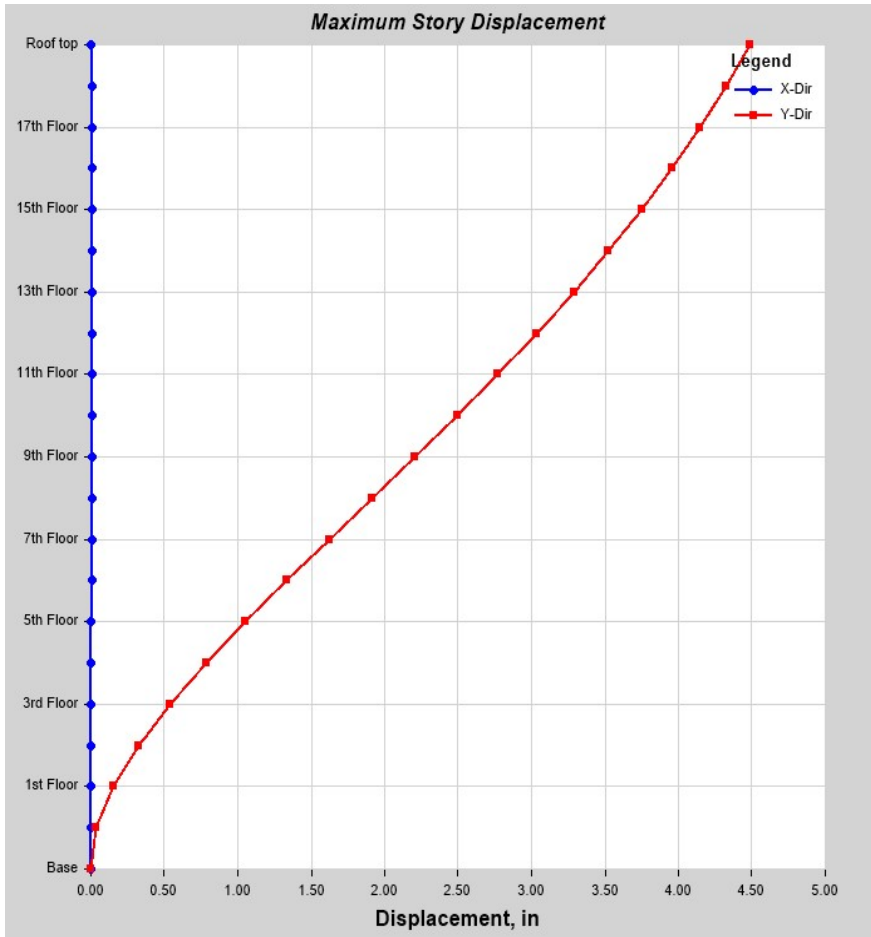

Square Shape Structure

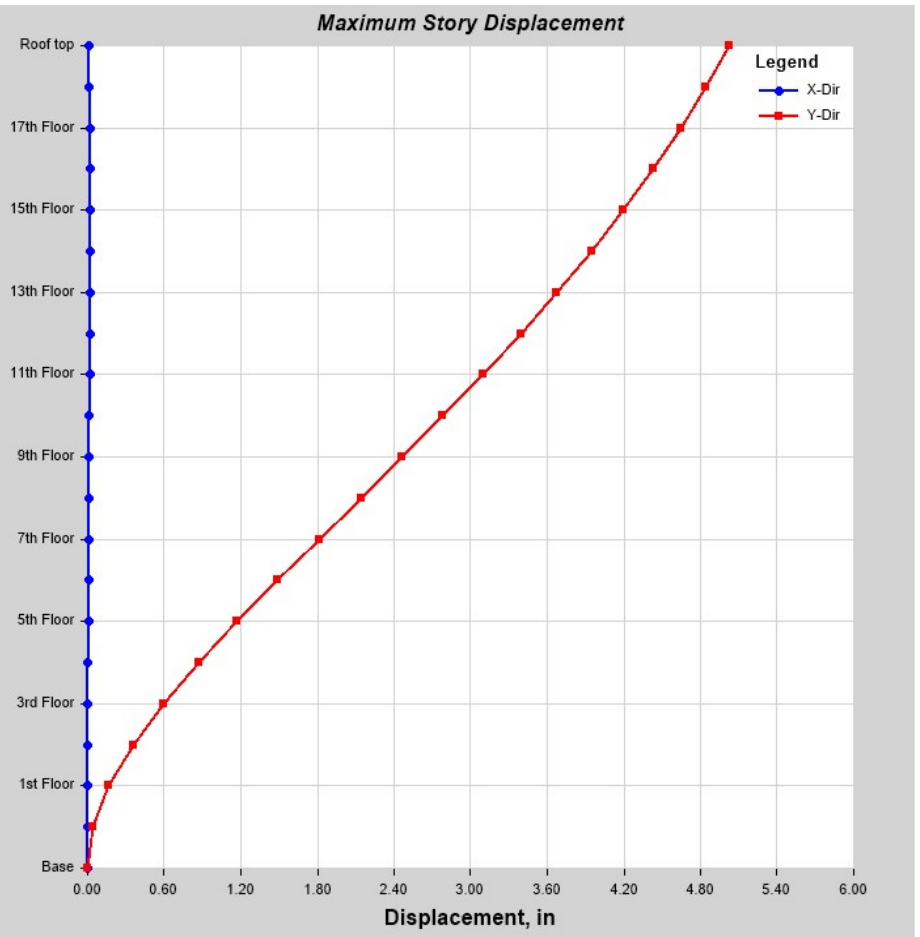

Circular Shape Structure

Fig-5b: Maximum Story Displacement in global Y direction.

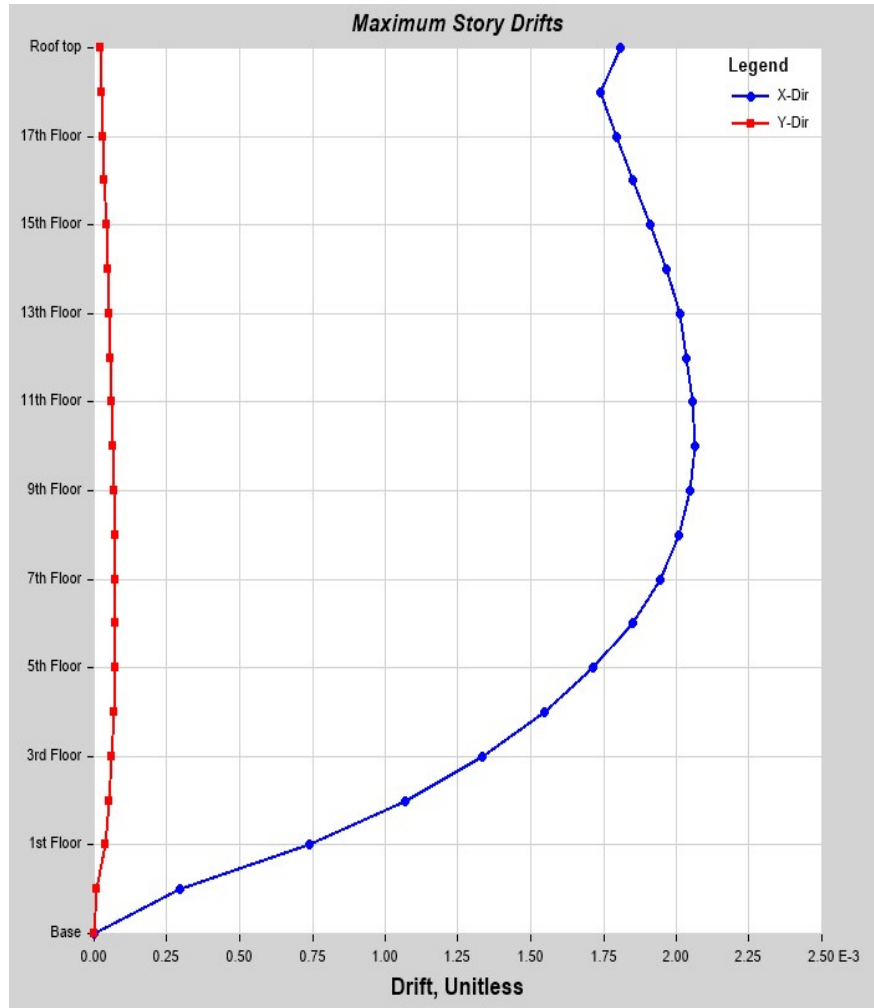

Square Shape Structure

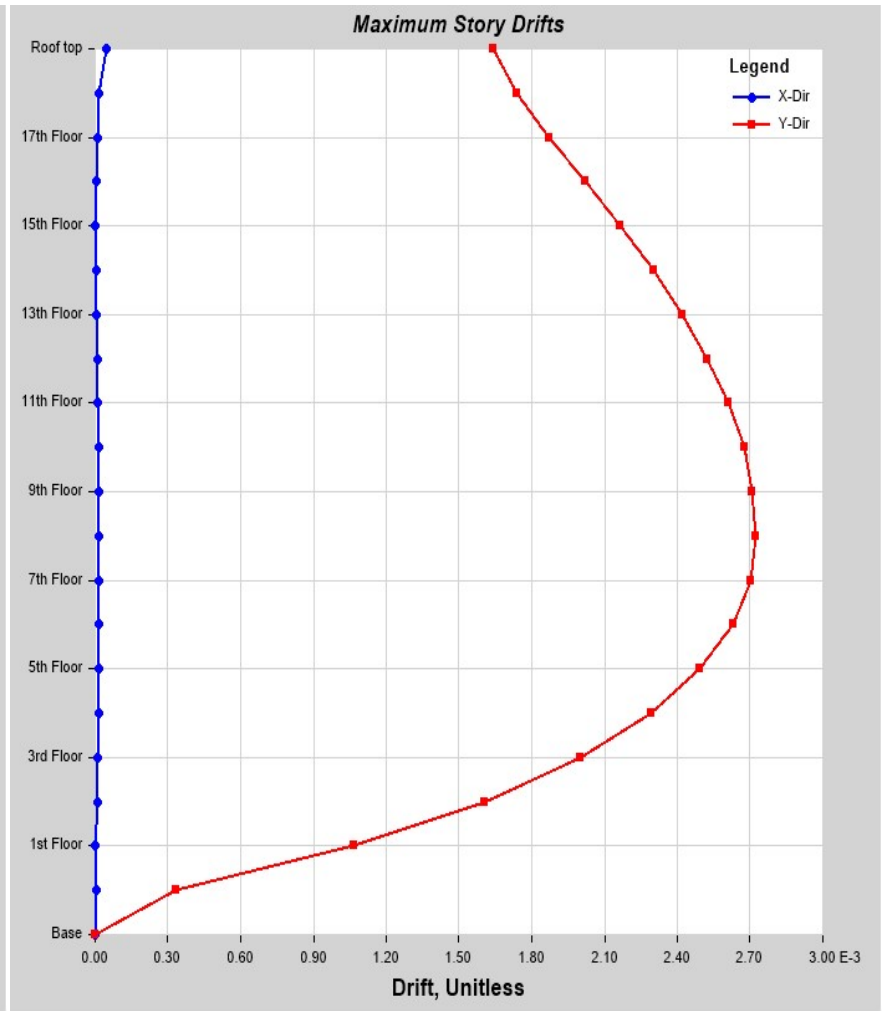

Circular Shape Structure

Fig-6a: Maximum Story Drifts in global X direction. 


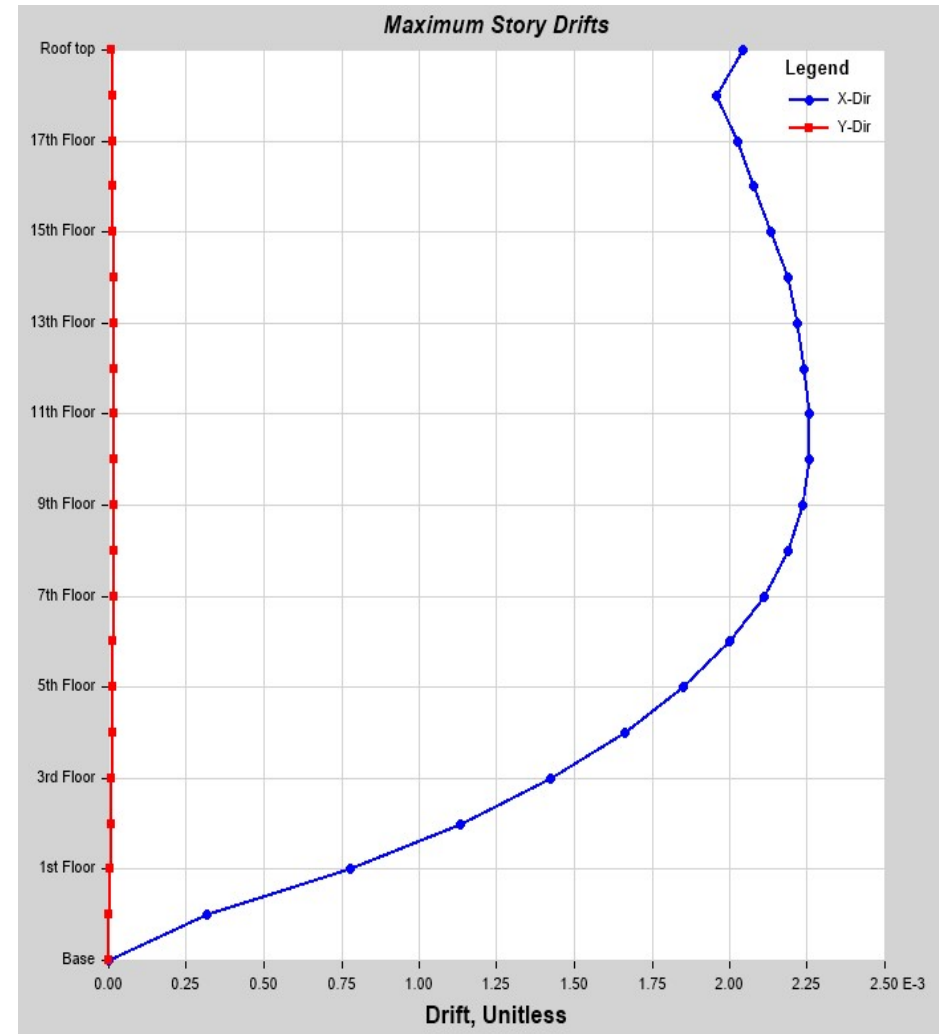

Square Shape Structure

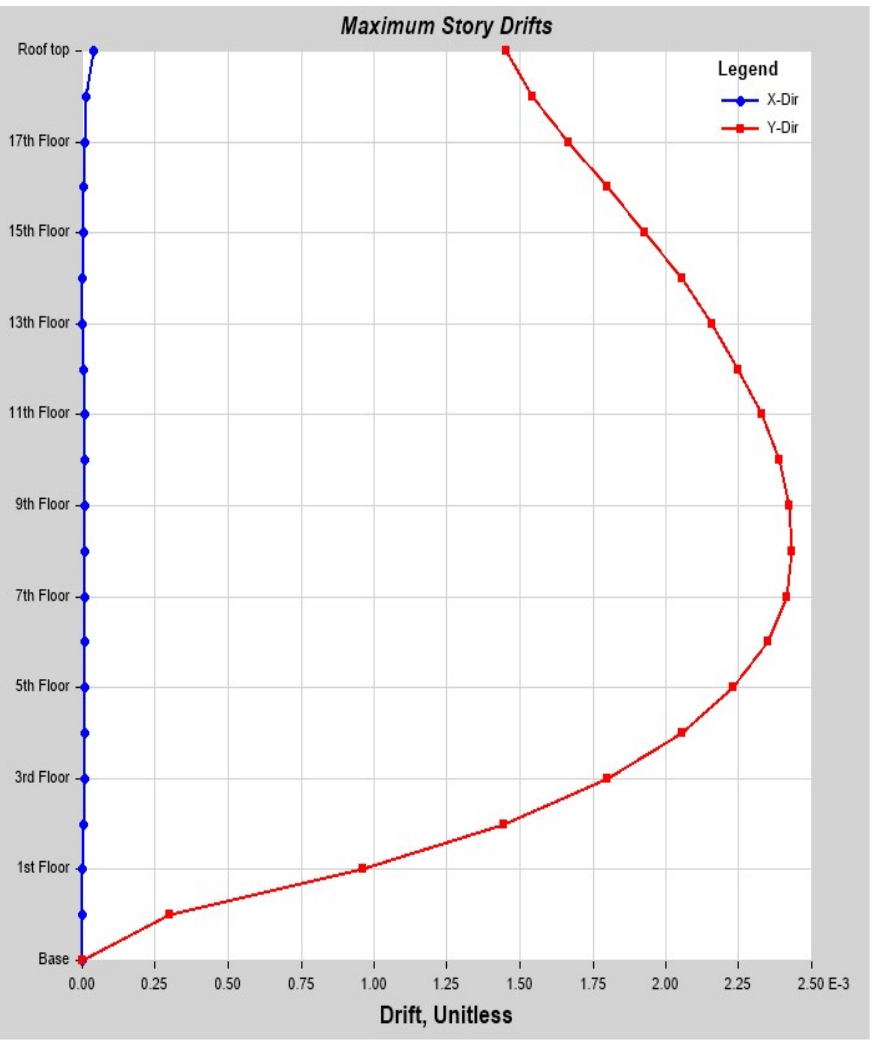

Circular Shape Structure

Fig-6b: Maximum Story Drifts in global Y direction.

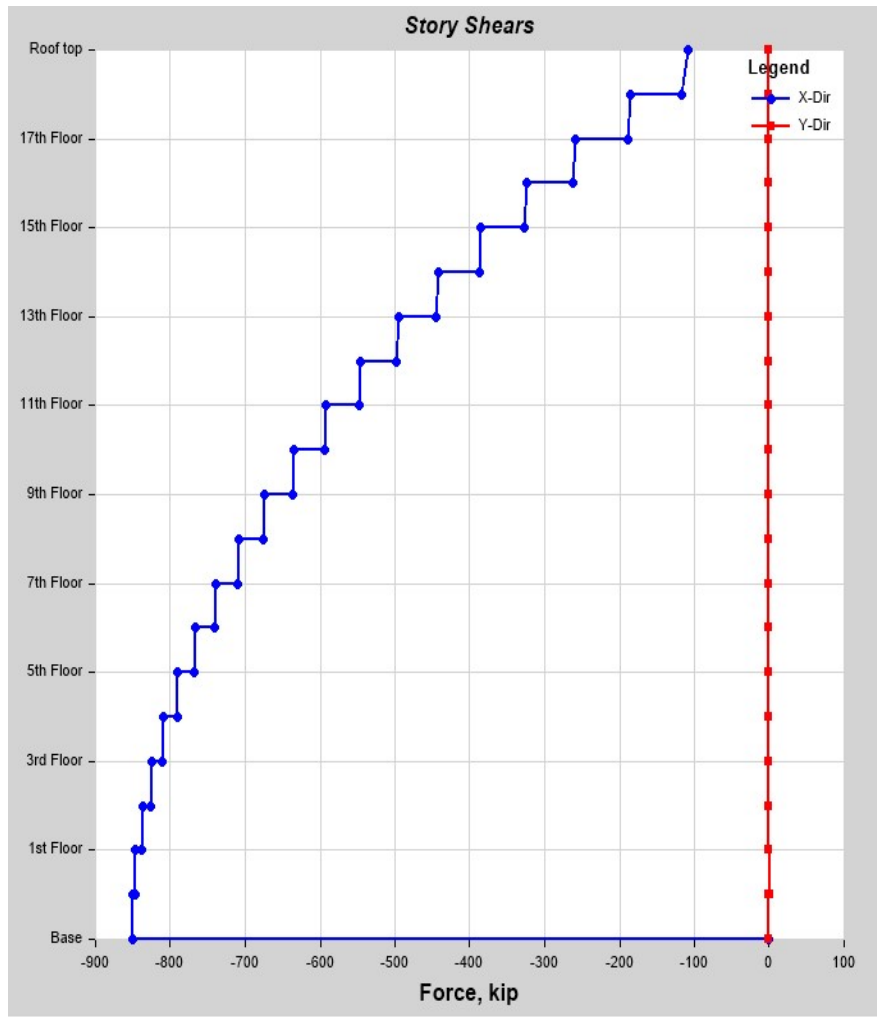

Square Shape Structure

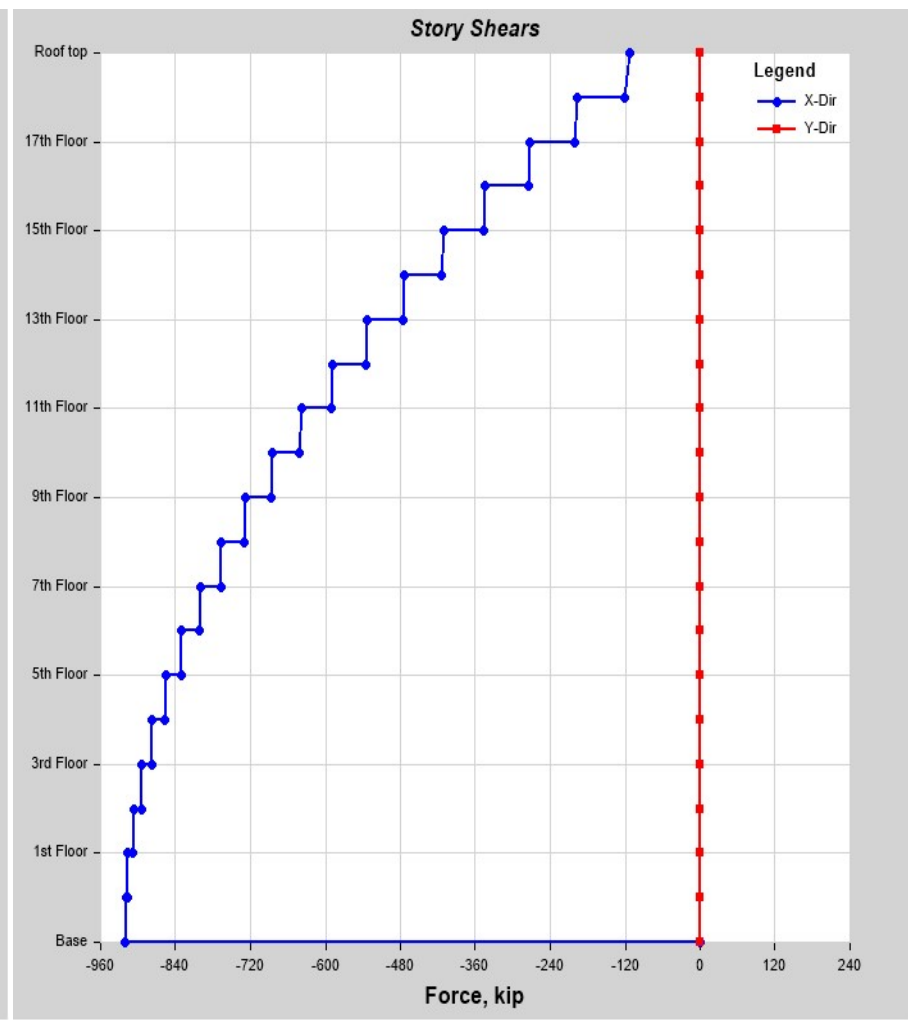

Circular Shape Structure

Fig-7a: Story Shears in global $\mathrm{X}$ direction 


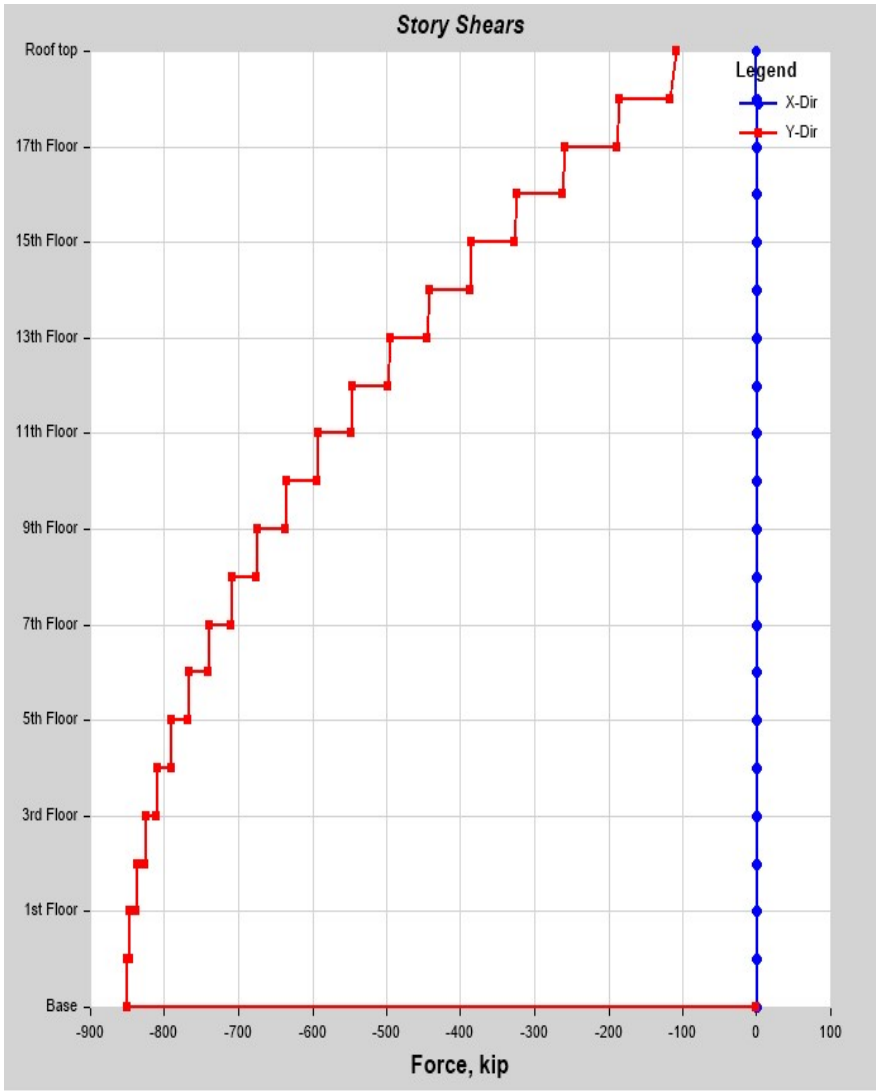

Square Shape Structure

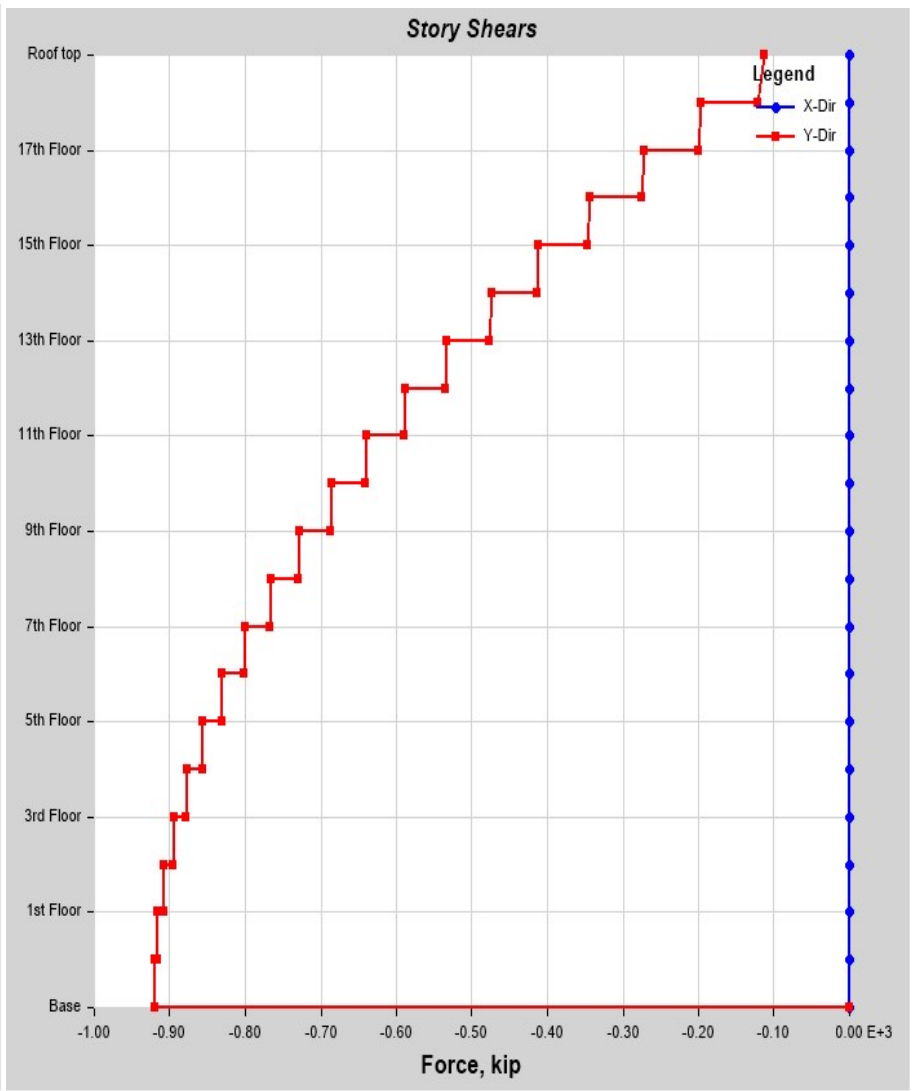

Circular Shape Structure

Fig-7b: Story Shears in global Y direction

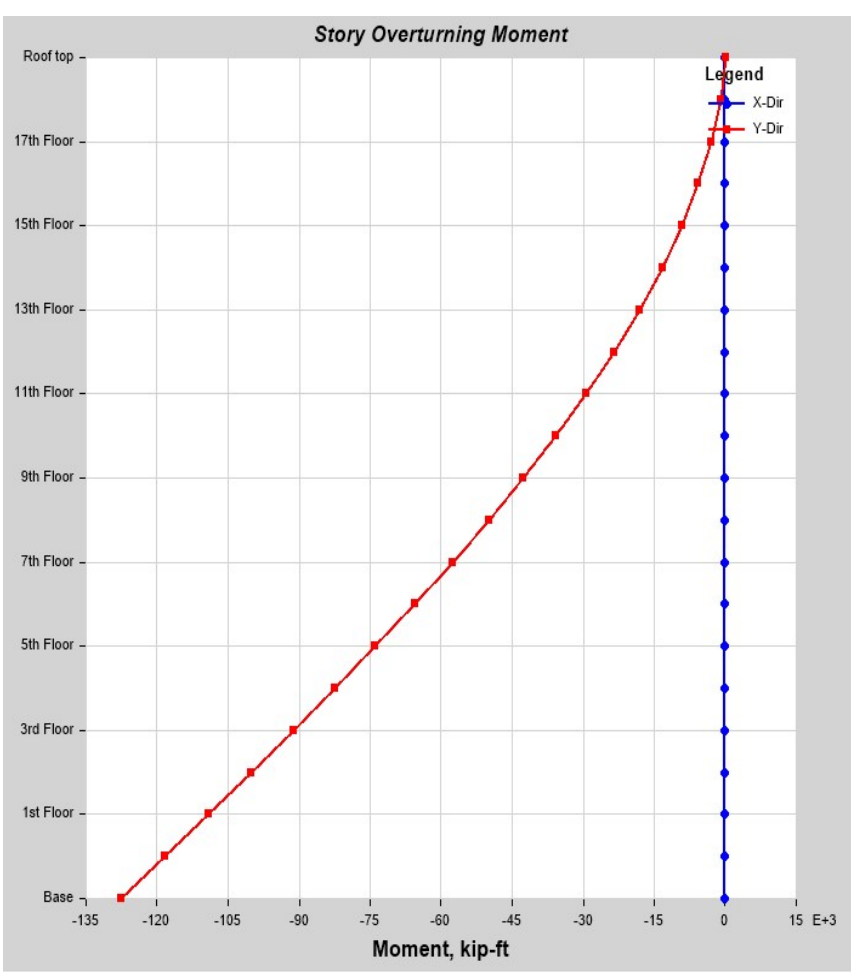

Square Shape Structure

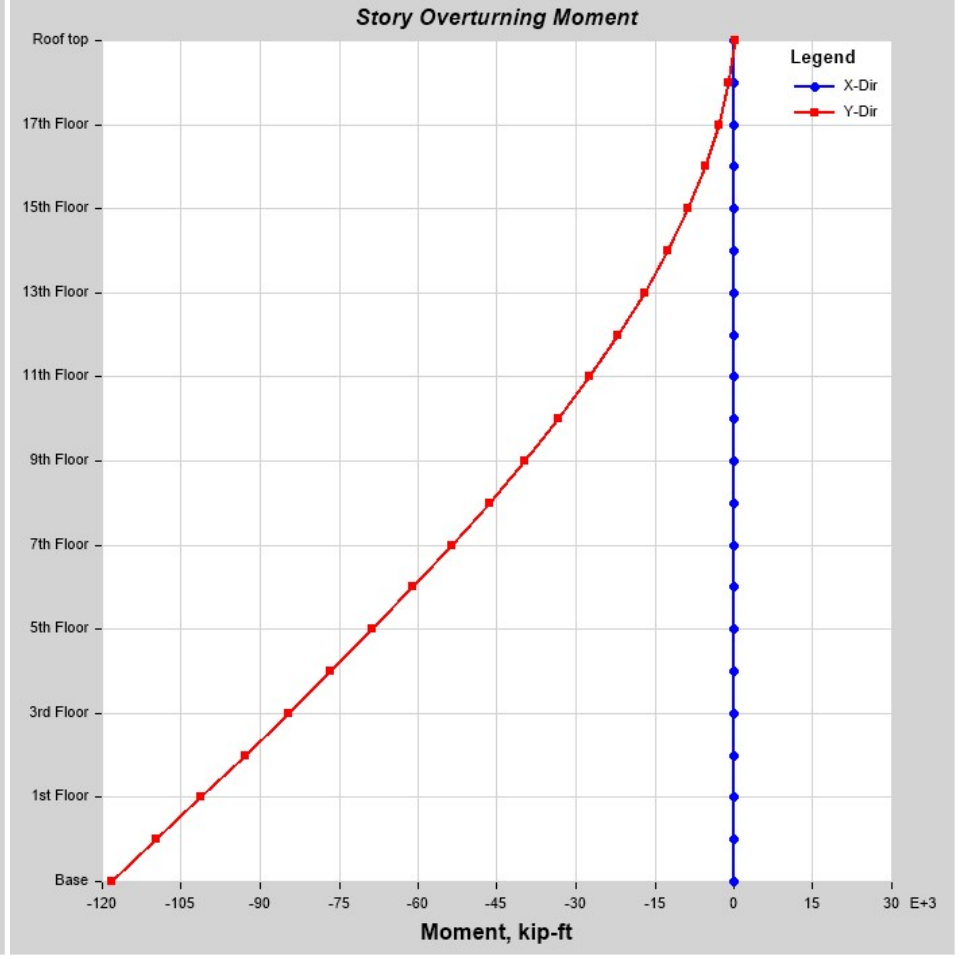

Circular Shape Structure

Fig-8a: Story Overturning Moments in global X direction 


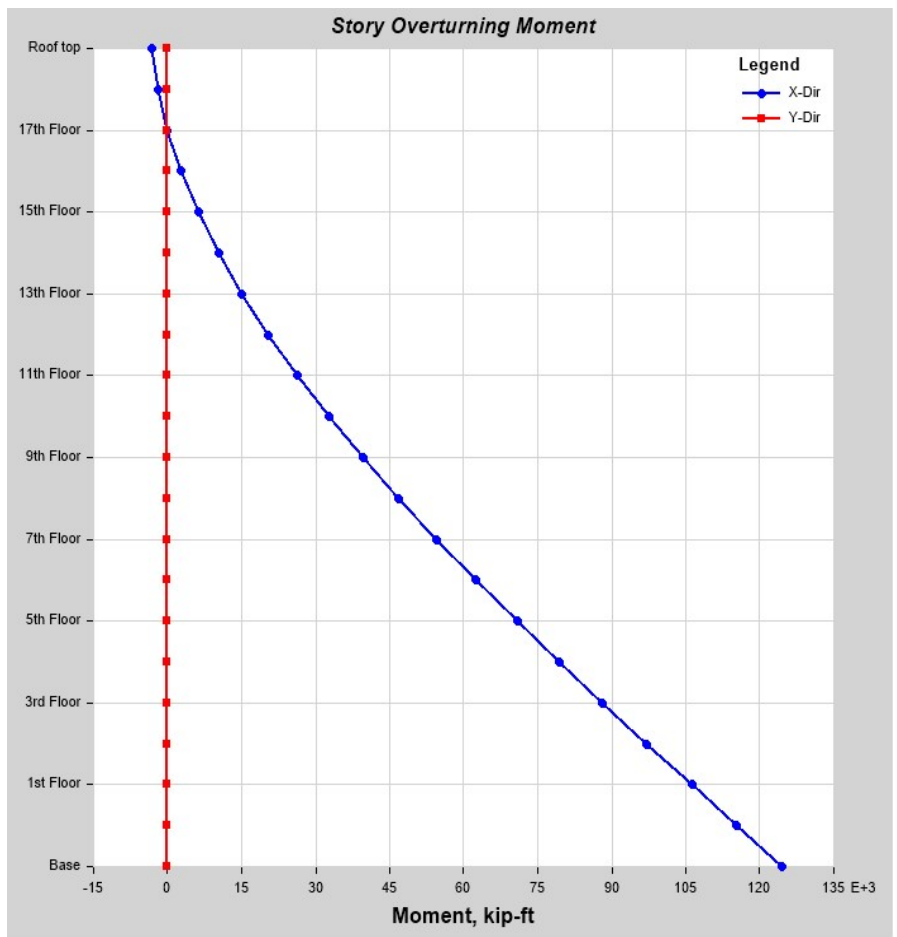

Square Shape Structure

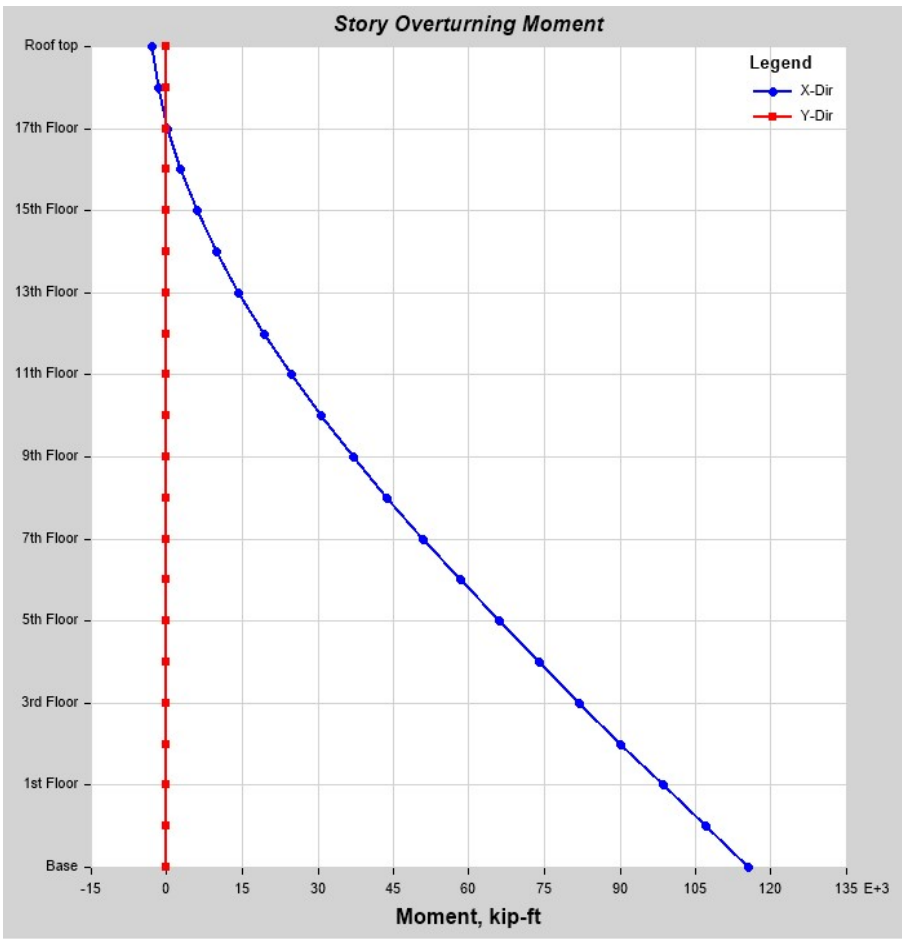

Circular Shape Structure

Fig-8b: Story Overturning Moments in global Y direction

\subsection{Story Stiffness}

Fig 9 ( $a \sim b)$ illustrated below provide information about the response for story stiffness. Here the horizontal axis represents story stiffness in kip-inch and the vertical axis represents the stories of the building. Blue curves state the response due to lateral loads implying in $\mathrm{X}$ direction of the model and red curves in $\mathrm{Y}$ direction. From figures, it is clearly seen that, circular shape structure has lower stiffness compared to square shape structure.

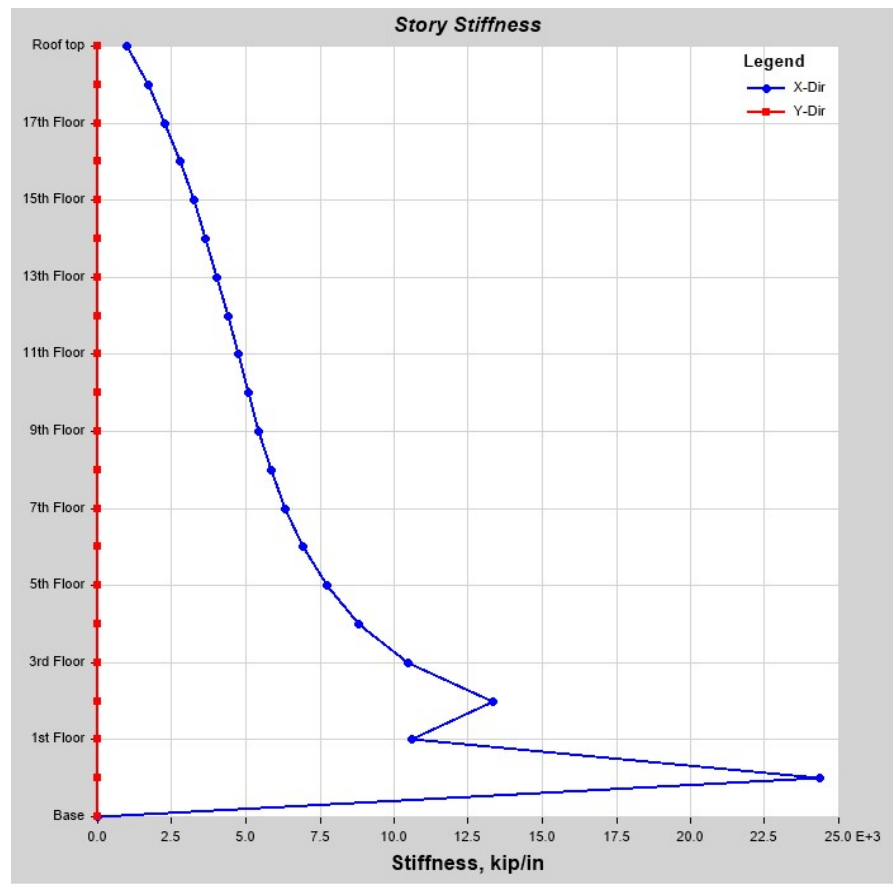

Square Shape Structure

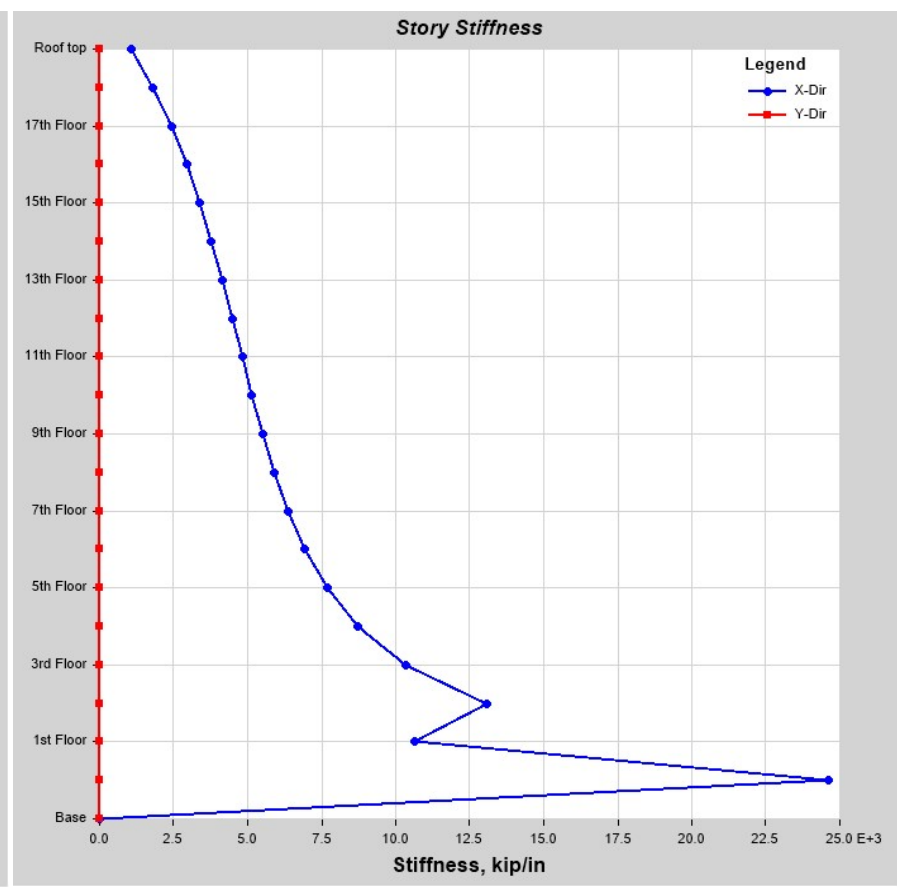

Circular Shape Structure

Fig-9a: Story Stiffness in global X direction 


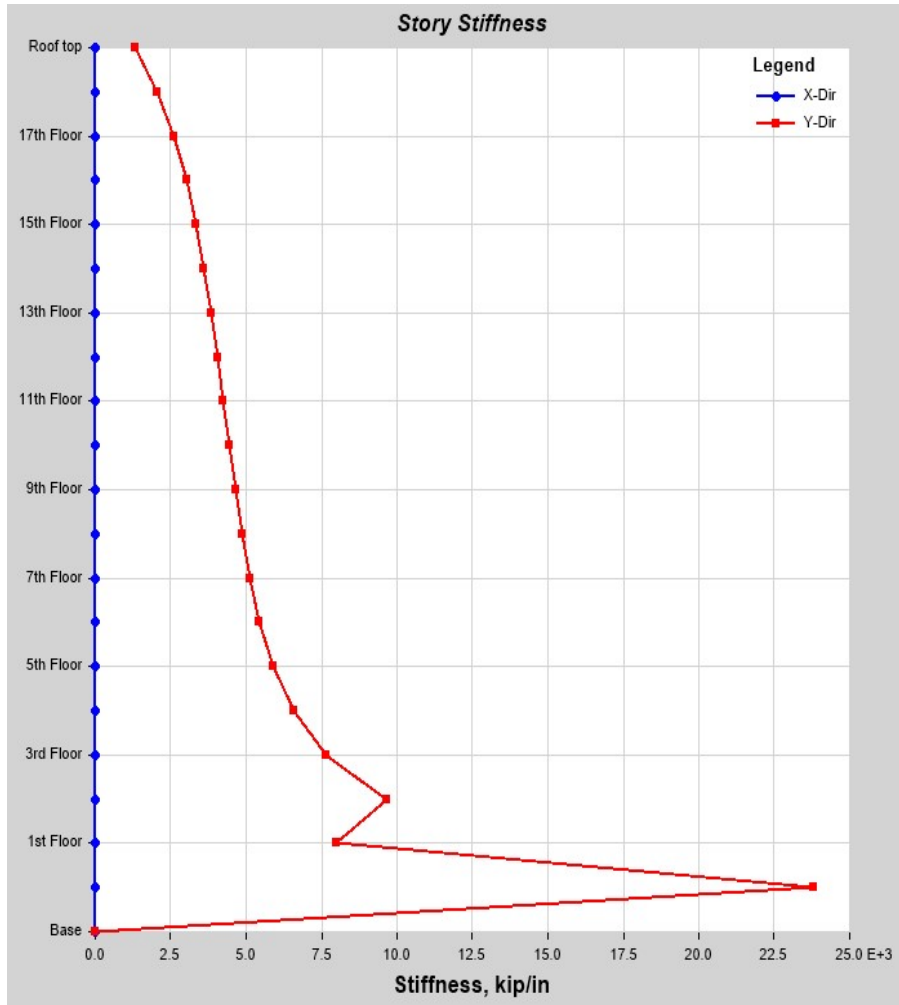

Square Shape Structure

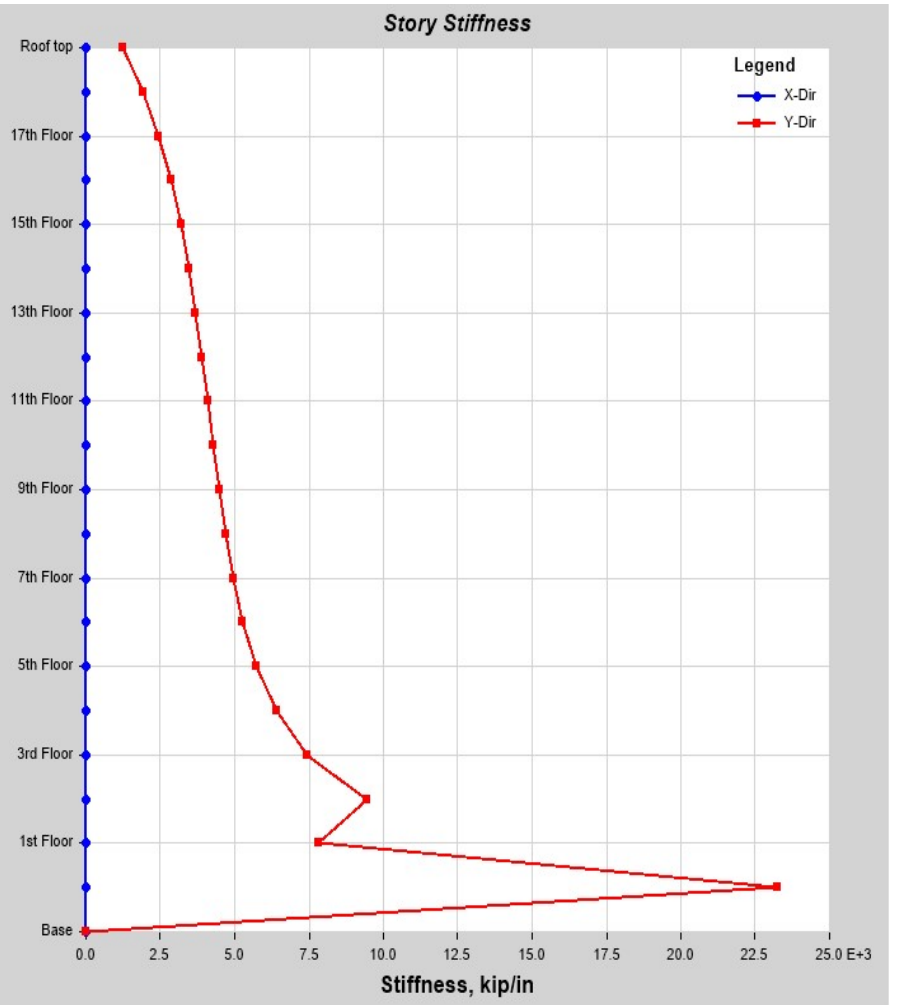

Circular Shape Structure

Fig-9b: Story Stiffness in global Y direction

\section{CONCLUSION}

From this analysis \& findings, it can be concluded that:

- Circular Shape structure shows greater story displacement at top floor compared to Square Shape structure.

- Circular Shape structure can resist higher story overturning moment at base compared to Square Shape structure.

- Circular Shape structure can resist higher story shear at base compared to Square Shape structure.

- Square Shape structure is stiffer than Circular Shape structure.

- Circular Shape structures have higher story drift compared to Square Shape structure.

- Overall, it can be justified that Circular shape structure is the best one against lateral loadings with compared to Square shape structure.

\section{ACKNOWLEDGMENT}

The authorsare thankful for support and cooperation during the research works to Mr. Md. Mehedi Hasanand Mr. Meskat Jamil who were the final year students and direct Research Assistants.

\section{REFERENCES}

[1]. "Seismic Design of Buildings and Bridges", Williams A.; Oxford University press, New York, 2003.

[2]. "Tall Building Structures", Smith B.S. and Coull A.; John Wiley \& Sons, Inc., New York, 1991.
[3]. "High Rise Building Structures", Schueller, Wolfgang; John Wiley \& Sons, Inc., New York, USA.

[4]. "Reinforced Concrete Fundamentals", Ferguson P. M., Breen J. E. and Jirsa J. O.; $5^{\text {th }}$ Edition, John Wiley \& Sons, Inc., New York, 1987.

[5]. "Bangladesh National Building Code", $1^{\text {st }}$ Edition, City Art Press, Dhaka, Bangladesh, 1993.

[6]. "American Concrete Institute Building Design Code", ACI, New York, USA, 2011.

[7]. "Floor Shape Optimization for Green Building Design", W. Wang et al., Advanced Engineering Informatics 20, 2006, Page 363-378.

\section{BIOGRAPHIES}

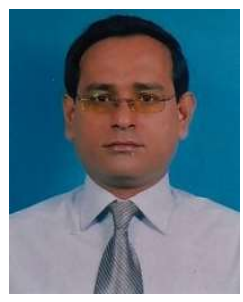

Md. Mahbub-ul-Alam, Graduated in Civil Engineering from the Chittagong University of Engineering and Technology [CUET], Chittagong, Bangladesh, in 1996, and received the M. ENGG. degree in Structural Engineering \& Construction from the Asian Institute of Technology, Bangkok, Thailand in 2000. At the same Institute, he worked as Research Associate in the School of Civil Engineering from 2000 to 2001. Recently he has been working as Assistant Professor in the Department of Civil Engineering of Stamford University, Dhaka, Bangladesh since 2007. He joined here in 2004. He is author or coauthor of scientific papers presented at international conferences or published in reviewed journals. His current research interests include Earthquake Engineering, Civil Engg. Materials and Testing, 
Repair \& Defects of RCC Structures, High Rise Structure

Modelling, Advanced Civil Engineering, Shear Characteristics of Beam \& columns, Recycled Aggregate, Durability of Existing Structures, Cracks in RCC structures, Marine structures. He is Reviewers of many national and international peer reviewed journals. He is the Fellow of Engineers Institution of Bangladesh and Member of American Concrete Institute. He is also connected with national and international several social and volunteers' organizations.

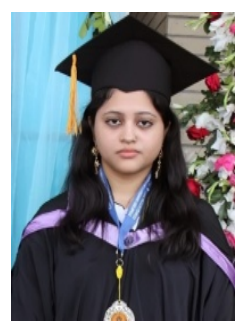

Farjana Akter, Graduated in Civil Engineering from Stamford University, Dhaka, Bangladesh, in 2011, and presently studying in M.Sc. in Structural Engineering at Bangladesh University of Engineering and Technology [BUET], Dhaka, Bangladesh. Recently she has been working as Lecturer in the Department of Civil Engineering of Stamford University, Dhaka, Bangladesh since 2015. She is author or coauthor of scientific papers published in reviewed journals. Her current research interests include Civil Engg.Materials and Testing, Structural modeling of high rise building etc. 